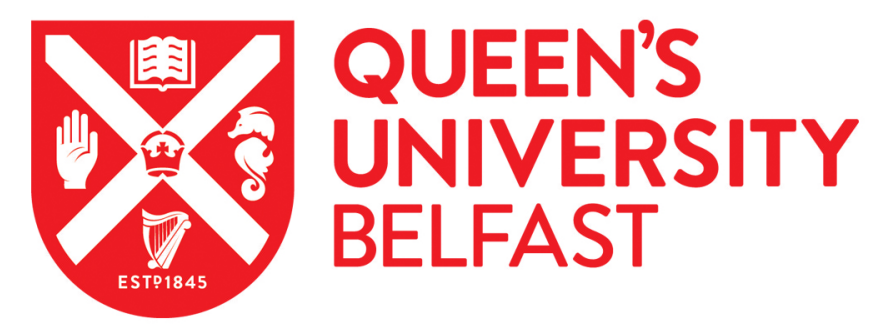

\title{
Combined effects of warming and nutrients on marine communities are moderated by predators and vary across functional groups
}

White, L., Donohue, I., Emmerson, M., \& O'Connor, N. (2018). Combined effects of warming and nutrients on marine communities are moderated by predators and vary across functional groups. Global Change Biology, 24(12), 5853. https://doi.org/10.1111/gcb.14456

Published in:

Global Change Biology

Document Version:

Peer reviewed version

Queen's University Belfast - Research Portal:

Link to publication record in Queen's University Belfast Research Portal

Publisher rights

Copyright 2018 Wiley. This work is made available online in accordance with the publisher's policies. Please refer to any applicable terms of use of the publisher.

\section{General rights}

Copyright for the publications made accessible via the Queen's University Belfast Research Portal is retained by the author(s) and / or other copyright owners and it is a condition of accessing these publications that users recognise and abide by the legal requirements associated with these rights.

Take down policy

The Research Portal is Queen's institutional repository that provides access to Queen's research output. Every effort has been made to ensure that content in the Research Portal does not infringe any person's rights, or applicable UK laws. If you discover content in the Research Portal that you believe breaches copyright or violates any law, please contact openaccess@qub.ac.uk. 
MISS LYDIA JANE WHITE (Orcid ID : 0000-0002-7531-5168)

DR. IAN DONOHUE (Orcid ID : 0000-0002-4698-6448)

Article type : Primary Research Articles

Combined effects of warming and nutrients on marine communities are moderated by predators and vary across functional groups

Running head: Predators alter warming and nutrient effects

Lydia White $^{1 *}$

Ian Donohue ${ }^{2}$

Mark C. Emmerson ${ }^{1}$

Nessa E. O’Connor ${ }^{1,2}$

1. School of Biological Sciences, Queen’s University Belfast, Belfast BT9 7BL, UK

2. Department of Zoology, School of Natural Sciences, Trinity College Dublin, Ireland

*Corresponding Author

Lydia White

This article has been accepted for publication and undergone full peer review but has not been through the copyediting, typesetting, pagination and proofreading process, which may lead to differences between this version and the Version of Record. Please cite this article as doi: $10.1111 / \mathrm{gcb} .14456$

This article is protected by copyright. All rights reserved. 
lwhite18@qub.ac.uk

Phone: +44 (0)2890972030

Keywords: biodiversity loss, consumers, nutrient enrichment, climate change, multiple stressors, ecosystem functioning, rocky shore, intertidal

Paper type: Primary Research Article

\begin{abstract}
Warming, nutrient enrichment and biodiversity modification are among the most pervasive components of human-induced global environmental change. We know little about their cumulative effects on ecosystems, however, even though this knowledge is fundamental to predicting and managing their consequences in a changing world. Here, we show that shifts in predator species composition can moderate both the individual and combined effects of warming and nutrient enrichment in marine systems. However, all three aspects of global change also acted independently to alter different functional groups in our flow-through marine rock-pool mesocosms. Specifically, warming reduced macroalgal biomass and assemblage productivity, whereas enrichment led to increased abundance of mesoinvertebrate consumers, and loss of predator species led to increased gastropod grazer biomass. This disparity in responses, both across trophic levels (macroalgae and intermediate consumers), and between detecting additive effects on aggregate measures of ecosystem functioning, yet interactive effects on community composition, illustrates that our forecasting ability depends strongly on the level of ecological complexity incorporated within global change experiments. We conclude that biodiversity change - and loss of predator species in
\end{abstract}

This article is protected by copyright. All rights reserved. 
particular - plays a critical and overarching role in determining how ecological communities respond to stressors.

\section{Introduction}

A key challenge in understanding and predicting the effects of global environmental change is the fact that multiple stressors often occur simultaneously (Crain et al., 2008; Halpern et al., 2008; García Molinos \& Donohue, 2010; Côté et al., 2016; Gunderson et al., 2016). This can make detection of impacts and prioritisation of management responses especially difficult. Among the most pervasive stressors in many ecosystems globally are warming, nutrient enrichment and biodiversity loss (Lotze et al., 2006; Nash et al., 2017). In spite of their ubiquity, we know little about the cumulative impacts of these stressors on marine communities (Vye et al., 2015). Such knowledge is essential both to predict and manage for their combined consequences in a changing world.

A global increase in mean surface temperature of $1-3.7^{\circ} \mathrm{C}$ is expected by the end of this century (relative to 1986-2005; IPCC 2013). This warming is expected to have considerable direct impacts on species via physiological stress and by altering both rates (Nemani, 2003) and the nature (Jöhnk et al., 2008) of primary production. Warming has been shown to trigger consistent responses across highly divergent communities, from bacteria to protists to metazoans over short time scales (akin to a heat wave; Smale et al., 2017). However, at the physiological level, warming can provide both opportunities for and constraints on competitors, with these dual effects being unequal among species (Kordas et al., 2011; Monaco and Helmuth, 2011). Consequent changes in interspecific interactions can, in turn, drive important local-scale changes in community dynamics (Kordas et al., 2011), constraining responses to warming (Gruner et al., 2017). Despite considerable community-

This article is protected by copyright. All rights reserved. 
specific idiosyncrasies, primary producers are nonetheless predicted to exhibit a weaker response to temperature compared to consumers (Yvon-Durocher et al., 2010; O'Connor et al., 2009), due to reduced sensitivity of photosynthesis to warming relative to respiration (Allen et al. 2005; Padilla-Gamino \& Carpenter, 2007). Warmer temperatures will, therefore, likely lead to stronger top-down control of primary production (O'Connor et al., 2009), increased grazer-algal interaction strengths (Sampaio et al., 2017) and associated shifts in food-web structure (Eklöf et al., 2012), with knock-on effects that will propagate throughout ecological networks (Sanford, 1999; Kordas et al., 2017).

Eutrophication of coastal waters caused by nutrient enrichment has increased greatly over the last two centuries (Smith et al., 1999), with significant consequences for the structure (O'Gorman et al., 2012; O’Connor \& Donohue, 2013) and functioning (O'Connor et al., 2015) of biotic communities.

Expected increases in the incidence of floods and precipitation events associated with climate change is likely to exacerbate these impacts even further (Jochum et al., 2012), via an increase in surface runoff and associated nutrient loading (Sinha et al., 2017), leading to resource-driven shifts in trophic dynamics. However, because respiration is more sensitive to warming than photosynthesis (Allen et al., 2005; Yvon-Durocher et al., 2010), the impacts of warming could offset those of enrichment via increased resource demand. The ecological consequences of these two components of global change may, therefore, cancel each other out (Shurin et al., 2012; McElroy et al., 2015). Alternatively, enrichment could magnify any warming-induced increases in productivity and growth by decreasing metabolic constraints that are associated with nutrient availability (Tadonléké, 2010). It is clear that non-additive interactions can occur when these two non-linear (i.e., positive resource and negative stressor; Harley et al., 2017) components of environmental change overlap, potentially leading to complex cumulative effects (Mckee et al., 2002; Kratina et al., 2012).

This article is protected by copyright. All rights reserved. 
Biodiversity loss is a globally-pervasive consequence of human activities and a major driver of ecosystem change (Worm et al., 2006; Hooper et al., 2012). Despite a disproportionately large risk of extinctions for species at higher trophic levels (Petchey et al., 1999; Terborgh et al., 2001; Duffy, 2002; Estes et al., 2011), and a large body of research focusing on species loss and multiple stressors in aquatic systems, the majority of studies have addressed effects of grazers on algal communities (Blake \& Duffy, 2010, 2012; Alsterberg et al., 2013;

Mrowicki et al., 2016) and ecosystem processes (O'Connor et al., 2015) and how grazer-algal interaction strengths vary with environmental change (Eklöf et al., 2012; O'Connor \& Donohue, 2013; Mrowicki \& O’Connor, 2015; Ghedini et al., 2015; Sampaio et al., 2017). Top-down effects of predator species loss are, however, relatively understudied, even though predators play particularly important roles in maintaining the structure (Bruno \& O'Connor, 2005; O’Gorman et al., 2008; Baum \& Worm, 2009; O’Connor et al., 2013; McClean et al., 2015) and stability (Estes et al., 2011; Griffin \& Silliman, 2011) of communities. Their loss can, for example, trigger dramatic secondary extinction cascades in natural communities, via shifts in both trophic and non-trophic interactions (e.g. predator-avoidance behaviour and competition for space; Donohue et al., 2017). Understanding community-level responses to warming and nutrient enrichment - and whether predator-mediated species interactions can help to resist such impacts (sensu Pimm,1984) - across different trophic levels and functional groups is therefore of critical importance.

Rocky shores are highly productive habitats, structured by a combination of interacting biotic and abiotic processes (Connell, 1972; Menge \& Sutherland, 1987). A combination of cascading predation effects, competitive interactions and direct consumption regulate algal communities (Hawkins 1981; Jenkins et al. 2005; O’Connor \& Crowe 2005; Coleman et al. 2006; O'Connor et al., 2013). Changes in consumer foraging patterns and subsequent growth rates on rocky shores as a result of predator-

This article is protected by copyright. All rights reserved. 
avoidance behaviour can also contribute to community dynamics and stability (Trussell et al., 2002, 2003; Donohue et al., 2017). In addition to strong forcing from physical gradients, rocky shore communities are also exposed to numerous anthropogenic pressures (Thompson et al., 2002; Harley et al., 2006), such as nutrient enrichment, habitat alteration and overexploitation which can result in declines and extirpation of consumer species (Thompson et al., 2002; Airoldi \& Beck, 2007; Airoldi et al., 2008), and coincide with more widespread climate-associated shifts in assemblages (Harley et al., 2006; Helmuth et al., 2006; Mieszkowska et al., 2006).

Here, we examine the individual and combined effects of ocean warming and nutrient enrichment on marine rocky shore communities and test whether their impacts can be mitigated by the presence or composition of predators. Using flow-through mesocosms designed to mimic natural multitrophic marine rock-pool communities, we manipulated temperature, nutrient conditions and the presence of two common intertidal predators, the shore crab Carcinus maenas and the dogwhelk Nucella lapillus, both separately and together, in a fully-factorial experiment. Our outdoor mesocosms have the benefit of maximising realism as far as possible while allowing highly-replicated and controlled conditions (Stewart et al., 2013). Thus, whilst they simplify natural systems, mesocosm experiments enable the isolation and measurement of causal mechanisms at ecologically meaningful scales (Benton et al., 2007; Yvon-Durocher \& Allen, 2012; Ghedini \& Connell, 2016). Specifically, we tested whether: (1) the presence of predators moderates the individual and / or combined effects of warming and nutrient enrichment on primary producers (macroalgae) and intermediate consumers (gastropod grazers and meso-invertebrates) and their associated rates of functioning; (2) these effects vary with predator species composition; and (3) different functional groups (i.e. macroalgae, gastropod grazers and meso-invertebrates) vary in their responses.

This article is protected by copyright. All rights reserved. 


\section{Materials and methods}

\section{Experimental design}

We established our experiment in eighty outdoor flow-through marine mesocosms located at Queen's University Marine Laboratory, Portaferry, Northern Ireland. The mesocosms comprised opaque propylene boxes (internal dimensions: L 55.5 x W 35.5 x H $22 \mathrm{~cm}$ ) enclosed with lids of fine plastic mesh, arranged in shallow tables (ten mesocosms per table) and supplied with sand-filtered seawater from the adjacent Strangford Lough (see Mrowicki \& O’Connor, 2015). Our eight-week experiment commenced on $5^{\text {th }}$ October 2015.

Shallow coastal benthic assemblages were created in each mesocosm to mimic rock pool communities found on local shores. These are typical of the region, and were based on local field surveys. Assemblages comprised six algal species: Fucus serratus (24 g wet biomass, brown canopy alga); Halidrys sililiqua (17 g, brown canopy); Cladophora rupestris (9 g, green filamentous); Mastocarpus stellatus (9 g, red turf); Corallina officialis (6 g, red calcareous) and Ulva lactuca (5 g, green ephemeral). All algae were present at similar densities to those in local rock pools of similar size and depth. Algae were cleared of epiphytes manually using metal spatulas and were immersed briefly in an insecticide bath (Vitax Ltd. Py Garden Insect Killer, Coalville, UK) to remove unwanted epibiota. Algae were then attached to plastic mesh (20 mm mesh size) inlays in each mesocosm and seawater was aerated and renewed by dump buckets (approximate mean flow-through rate: $4 \mathrm{~L} \mathrm{~min}^{-1}$ ) to simulate wave action on rocky shores. Each mesh inlay had a nylon pot scourer (85 mm diameter and approximately $30 \mathrm{~mm}$ width) attached. Prior to the start of the experiment, the pot scourers were deployed in large plastic mesh pouches in the intertidal zone at Ballyhenry Island ( $\mathrm{N} 54^{\circ} 39^{\prime} 37^{\prime} \mathrm{W}$ $\left.5^{\circ} 57^{\prime} 61^{\prime}\right)$ on the shores of Strangford Lough and left for six weeks to allow colonisation by small invertebrate consumers. This type of pot scourer has been used previously and successfully as artificial habitat for sampling (e.g. O'Gorman et al., 2008; Matias et al., 2010), and comprises an ideal substrate for colonisation by mobile benthic invertebrate species (O'Gorman et al., 2010). Inspection

This article is protected by copyright. All rights reserved. 
of five pads set aside before the start of the experiment revealed them to be inhabited by a similar range of meso-invertebrate taxa, including Ophiuroidea, Copepoda, Amphipoda, Ostracoda, Isopoda, Gastropoda, Foraminifera, marine mites and the larvae of a variety of species, of sizes ranging from approximately 0.05 to $10 \mathrm{~mm}$.

Three factors were manipulated in our fully-factorial experimental design: predator composition (four levels: no predators, monocultures of each of the whelk Nucella lapillus and shore crab Carcinus maenus, and a polyculture containing both predator species); warming (two levels: ambient and elevated) and nutrient enrichment (two levels: ambient and enriched). Each of the resulting 16 treatment combinations was replicated five times. Treatments were allocated randomly to mesocosms, which were rearranged approximately weekly to minimise location artefacts (Bruno \& O'Connor, 2005).

Crabs and whelks are both highly susceptible to a range of anthropogenic pressures (Hawkins et al., 2002; Sheehan et al., 2010), making them extremely pertinent organisms for use in species loss experiments. Predator diversity was manipulated using a modified substitutive design, whereby the densities of species in polyculture (one crab and one whelk), were determined by dividing the respective monoculture densities (two crabs and two whelks) by the total number of species (Griffin et al., 2009a). Densities of grazers, predators and algae used in the experiment were chosen to reflect natural densities within rock pools on the low-mid shore at the collection site (Kearney, Co. Down; $\left.54^{\circ} 23^{\prime} 21^{\prime \prime} \mathrm{N}, 5^{\circ} 27^{\prime} 33^{\prime \prime} \mathrm{W}\right)$. Crabs used in the experiment had a carapace width of $61.2 \pm 1.2 \mathrm{~mm}$ (mean \pm S.E.) and wet biomass $56.4 \pm 3.2 \mathrm{~g}$. At this size, gastropods are an important component of their diet (Rangeley \& Thomas, 1987; Silva et al., 2008), while preliminary feeding trials suggested that smaller crabs were unlikely to feed on gastropod grazers used in the study. Although larger crabs have been found to feed on whelks (e.g. Hughes \& Elner, 1979), no predation by crabs upon whelks was observed in preliminary trials or during the experiment. Whelks used in the experiment measured

This article is protected by copyright. All rights reserved. 
$26.5 \pm 0.3 \mathrm{~mm}$ in length and weighed $3.9 \pm 0.1 \mathrm{~g}$. Both whelks and crabs were observed feeding upon gastropod grazers in preliminary trials and during the experiment.

Grazing gastropods were added to each mesocosm at the commencement of the experiment at densities similar to those found in surveys of local rock pools (i.e. the limpet Patella vulgata: 8.5 individuals $\mathrm{m}^{-2}$; winkle Littorina littorea: 23.4 individuals $\mathrm{m}^{-2}$; and topshell Gibbula umbilicalis: 13.5 individuals $\mathrm{m}^{-2}$ [hereafter 'Patella', 'Littorina' and 'Gibbula', respectively]). Two Patella (total wet biomass: $12.9 \pm 0.3 \mathrm{~g}$, mean \pm S.E. $)$, five Littorina $(16.5 \pm 0.1 \mathrm{~g})$ and four Gibbula $(5 \pm 0.1 \mathrm{~g})$ were therefore added to each mesocosm. All experimental organisms were acclimatized outdoors in flowing seawater at ambient temperatures for two weeks prior to the start of the experiment.

Elevated temperatures were achieved using aquarium heaters (Elite Submersible $300 \mathrm{~W}$, Hagen Inc., USA). Temperature was monitored weekly from the centre of each mesocosm for the duration of the experiment using a digital aquarium thermometer (Marina Aqua-Minder, Hagen Inc., USA). The mean temperature in warmed mesocosms over the course of the experiment was $1.9^{\circ} \mathrm{C}\left(15.2^{\circ} \mathrm{C}\right)$ greater than ambient levels $\left(13.3^{\circ} \mathrm{C}\right)$, simulating the predicted increase in sea surface temperature by 2080 in the Irish Sea (Hulme et al., 2002). Temperatures within rock pools from which organisms were collected from were also monitored weekly and were similar to those in mesocosms at ambient conditions (ANOVA; $F_{1,43}=2.89, P=0.09$ ). Data loggers (iButton thermochron DS1922L, Maxim Integrated Products Inc., USA) were used to record temperature every 15 minutes in a random subset of mesocosms $(n=3)$ within each temperature treatment. The mean daily temperature range was greater in heated mesocosms $\left(2.6^{\circ} \mathrm{C}\right)$ compared to those at ambient temperatures $\left(1.3{ }^{\circ} \mathrm{C}\right.$; ANOVA, $\left.F_{1,4}=45.06, P<0.001\right)$.

This article is protected by copyright. All rights reserved. 
Nutrient treatments reflected ambient conditions in Strangford Lough and an intensity of eutrophication consistent with that commonly observed in coastal marine environments (Smith et al., 1999). Ambient seawater contained (mean \pm SE) $2.77 \pm 0.14 \mu \mathrm{m} \mathrm{L}^{-1}$ dissolved inorganic nitrogen, $0.73 \pm 0.09 \mu \mathrm{m} \mathrm{L}^{-1}$ phosphate and $1.97 \pm 0.43 \mu \mathrm{m} \mathrm{L}^{-1}$ ammonium. Nutrient enrichment was achieved by addition of $140 \mathrm{~g}$ of Everris Osmocote ${ }^{\circledR}$ Exact (Geldermalsen, The Netherlands) slow release fertilizer pellets (11 N: $11 \mathrm{P}: 18 \mathrm{~K})$ to each mesocosm, divided equally among four perforated $50 \mathrm{~mL}$ falcon tubes (McElroy et al., 2015). The tubes were secured to the extruded mesh in each mesocosm with cable ties. Identical tubes containing gravel were included as procedural controls in unenriched mesocosms. Nutrient enrichment elevated inorganic nitrogen content in the mesocosms by approximately $70 \%$ (i.e. by $1.74 \pm 0.41 \mu \mathrm{m} \mathrm{L}^{-1}$; samples collected five weeks after commencement of the experiment), similar to previous nutrient enrichment studies (Worm et al., 2000; Canning-Clode et al., 2008; Sugden et al., 2008; Vye et al., 2015). Previous experiments in rock pools (O'Connor et al., 2015; Vye et al., 2018) have identified that this dosage can sustain suitably enhanced concentrations for at least eight weeks (i.e. the total duration of the experiment). Thus no further nutrients were added.

\section{Laboratory analyses}

At the end of the experiment, the biomass of each macroalgal species (after drying at $60^{\circ} \mathrm{C}$ until constant biomass was attained) was quantified to test for differences in macroalgal assemblage structure and total macroalgal biomass among treatments. Pot scourers were removed from all mesocosms to quantify abundances of meso-invertebrates. Individuals were stained with RoseBengal solution, counted and identified to as high a taxonomic resolution as practicable. Grazers and predators were remeasured and reweighed at the end of the experiment.

This article is protected by copyright. All rights reserved. 
Assemblage metabolic processes were used as proxies for ecosystem functioning, and were quantified at the end of the experiment from dissolved oxygen concentrations using an optical probe (Hach IntelliCAL ${ }^{\mathrm{TM}}$ LDO101) after periods of artificially-induced darkness and subsequent similar periods of sunlight (Nielsen, 2001; Noël et al., 2010). Initial oxygen concentration was measured and mesocosms were then covered immediately with a lid and subjected to a dark incubation period of $180-200$ minutes to quantify respiration. After incubation, a second set of oxygen measurements was made. A third set of measurements was then made after a further $100-200$ minute light period that allowed photosynthesis to resume. Before every oxygen measurement, the water within mesocosms was stirred gently to mix the water and disrupt stratification. Incubation periods varied to ensure that a quantifiable change in dissolved oxygen concentration was achieved (Noël et al. 2010). Oxygen flux rates were calculated from changes in dissolved oxygen concentrations over the time elapsed, taking into account mesocosm volume, and converted into units of carbon (Stutes et al., 2007; Antón et al., 2009, 2011). Gross assemblage productivity (GAP) was calculated from the sum of estimates of net assemblage productivity (NAP) and assemblage respiration (AR).

Photosynthetically active radiation (PAR) was recorded during oxygen concentration measurement (using a Skye Instruments Ltd. Quantum Sensor, Llandrindod-Wells, Wales). Mean PAR was $495 \pm$ $26 \mu \mathrm{mol}$ photons $\mathrm{s}^{-1} \mathrm{~m}^{-2}$ (mean \pm S.E., $n=129$ ), comparable to that recorded as saturating light in similar rocky shore assemblages (550 $\mu \mathrm{mol}$ photons s $\mathrm{m}^{-1}$; Arenas et al., 2009).

\section{Data analyses}

Analysis of variance (ANOVA) was used to test for additive and interactive effects of our experimental treatments on the total biomass of macroalgae and gastropod grazers, the total abundance of meso-invertebrates, and community metabolism. Models incorporated all individual and interactive combinations of nutrient enrichment, temperature and predator composition. Prior to analyses, data normality and homoscedasticity were assessed using, respectively, Shapiro-Wilk and Levene's tests. Data were transformed where necessary; macroalgal biomass and meso-invertebrate

This article is protected by copyright. All rights reserved. 
abundance were log-transformed and grazer biomass was squared to meet statistical assumptions. Student-Newman-Keuls (SNK) tests were used to make post-hoc comparisons among levels of significant terms.

Permutational multivariate analysis of variance (PERMANOVA; Anderson, 2001;

McArdle \& Anderson, 2001) was used to test for additive and interactive effects of our experimental treatments on the structure of macroalgal, meso-invertebrate and gastropod grazer assemblages at the end of the experiment, based on the same model structure as the ANOVAs. All tests involved 9,999 permutations of residuals under a reduced model and were based on Bray-Curtis dissimilarities. Prior to analyses, data were checked for homogeneity of dispersions (Anderson, 2006), but transformations were not necessary. Post-hoc pairwise pseudo $t$-tests were used to reveal differences between levels of significant terms, and the relative contributions of individual species to these differences were determined using similarity of percentages analyses (SIMPER; Clarke \& Warwick, 2001). All analyses were performed in R (version 3.3.3; R Development Core Team, 2017), except for PERMANOVAs, which were done using the PERMANOVA+ add-on in PRIMER (version 6.1.13; PRIMER - E Ltd., Plymouth, UK).

\section{Results}

\section{Macroalgae}

The total biomass of macroalgae was reduced by warming (Table 1a, Fig 1a). This effect was not modified by either predation or nutrient enrichment. In contrast, predators determined the effects of warming and nutrients on macroalgal assemblage structure - we found that macroalgal assemblage structure varied significantly among predator treatments, but that this effect interacted with both temperature and nutrient enrichment (Table 2a). Post-hoc tests were inconclusive, however assemblages differed between mesocosms containing only crabs and those with both predator species

This article is protected by copyright. All rights reserved. 
(PERMANOVA post-hoc tests; $P=0.009$ ) as well as those without predators $(P=0.008)$, but only when both warmed and nutrient enriched. These differences were driven primarily by reduced biomass of Fucus serratus and Halidrys siliquosa in crab monocultures compared to treatments where no predators were present and in mesocosms where both crabs and whelks were present (Table S1a,b). Macroalgal assemblages also differed between mesocosms containing only crabs and those with both predator species present but only at ambient temperatures and under nutrient enriched conditions $(P=0.031)$. This was caused by a greater biomass of $F$. serratus in crab monocultures and of Mastocarpus stellatus in predator polycultures (Table S1c). Macroalgal assemblages also varied between mesocosms containing only whelks and those with both predator species, but only at ambient temperatures and nutrient concentrations $(P=0.046)$. This difference was driven by greater abundance of both F. serratus and M. stellatus and less Cladophora rupestris and Halidrys siliquosa in predator polycultures compared to whelk monocultures (Table S1d). Warming also caused shifts in macroalgal assemblage structure, but only in mesocosms containing crab monocultures that were enriched with nutrients $(P=0.007)$, as a result of lower relative abundance of $F$. serratus and $M$. stellatus when warmed (Table S1e).

\section{Intermediate consumers}

Total biomass of gastropod grazers varied with predator composition (Table 1b, Fig 1b), regardless of nutrient concentrations or temperature. Grazer biomass was lower in crab monocultures and in predator polycultures than in whelk monocultures and the no predator treatment (SNK post-hoc tests; crab monoculture $<$ no predators: $P<0.001$; crab monoculture $<$ whelk monoculture: $P<0.001$; polyculture $<$ no predators: $P<0.001$; polyculture $<$ whelk monoculture: $P=0.003$ ). Grazer biomass was also lower in mesocosms containing whelk monocultures than those without predators $(P<$ $0.024)$.

This article is protected by copyright. All rights reserved. 
The assemblage structure of gastropod grazers was altered by predators, but this effect varied with nutrient enrichment (Table 2b). Although post hoc tests were unable to resolve treatment differences fully, grazer assemblages differed between mesocosms containing predator polycultures compared to those with only whelks, at ambient nutrient concentrations (PERMANOVA post-hoc tests; $P=$ 0.012). This was driven by greater relative biomass of Patella and Littorina in whelk monocultures (Table S2a). Grazer assemblages also differed between mesocosms containing both predator species compared to those with whelks $(P=0.002)$ and those lacking predators $(P=0.006)$, but only when nutrients were added. These differences were driven primarily by lower biomass of Patella in the predator polyculture compared to when just whelks or no predators were present (Table S2b,c). The identity of the predators in the system also determined the effects of enrichment - addition of nutrients altered grazer assemblages by reducing the relative biomass of Patella, but only in mesocosms containing predator polycultures $(P<0.001$; Table S2d).

Total abundance of meso-invertebrates was reduced by predators (although post hoc tests could not identify this conclusively; SNK post-hoc tests; no predators $>$ crab monocultures: $P=0.018$; no predators $>$ whelk monocultures: $P=0.027$ ), and was increased by nutrient enrichment (Table 1c, Fig. 1c). Predators modified the assemblage structure of meso-invertebrates, but this effect interacted with both nutrient enrichment and warming (Table 2c). Specifically, meso-invertebrate assemblages differed between mesocosms containing no predators compared to all treatments containing predators (PERMANOVA post hoc tests; polyculture - no predators: $P<0.023$; crab monoculture - no predators: $P<0.008$; whelk monoculture - no predators: $P<0.008)$, but only under both ambient temperatures and nutrient conditions. This was a consequence of greater abundance of nematode worms in mesocosms lacking predators (Table S3a-c). Nutrient enrichment altered meso-invertebrate assemblages in mesocosms with crab monocultures at ambient temperatures $(P=0.025)$, which contained greater abundances of nematodes and copepods relative to ambient nutrient conditions (Table S3d). Warming led to changes in meso-invertebrate assemblages in mesocosms without predators under ambient nutrient conditions $(P=0.009)$, and in mesocosms containing crab 
monocultures under enriched nutrient concentrations $(P=0.015)$, in both cases as a consequence of greater relative abundance of nematodes and copepods at ambient temperatures (Table S3e,f).

\section{Assemblage metabolism}

Both gross and net assemblage productivity were reduced significantly by warming (Table 3, Fig. 2). For net productivity this was largely a consequence of increased assemblage respiration in warmed mesocosms (Table 3b, Fig. 2b). Gross assemblage productivity was also greater in mesocosms containing both predator species compared with all other predator treatments (SNK post-hoc tests; polyculture $>$ crab monoculture: $P=0.015$; polyculture $>$ whelk monoculture: $P=0.007$; polyculture $>$ no predators: $P=0.009$, Fig. 2a). Assemblage respiration rates were greatest (i.e. highest rates of carbon loss) when crabs were present (crab monoculture $>$ whelk monoculture: $P=0.011$; crabs monoculture $>$ no predators: $P<0.001$; polyculture $>$ whelk monoculture: $P=0.005$, polyculture $>$ no predators: $P<0.001$, Fig. 2 b). Net assemblage productivity appeared to have been greater in mesocosms that contained both predator species compared with those containing only crabs $(P=$ 0.005, Fig. 2c). Post hoc tests could not, however, resolve differences among treatments fully.

\section{Discussion}

Our results show that predators can modify both the individual and combined effects of warming and nutrient enrichment in marine systems. Predators interacted with both components of environmental change to trigger shifts in algal and meso-invertebrate assemblages. Whereas warming independently reduced macroalgal biomass and assemblage productivity, loss of predators led to increased grazer biomass and meso-invertebrate abundance. Together, these findings demonstrate that changes in biodiversity are as important as, and can further complicate the direct effects of, global change (Hooper et al., 2012; O’Connor \& Donohue, 2013; Kordas et al., 2017). Conserving predator guilds has been shown to be instrumental in maintaining the stability of community dynamics (Griffin \&

This article is protected by copyright. All rights reserved. 
Silliman, 2011; O’Connor et al., 2013; Britten et al., 2014; Antiqueira et al., 2017; Donohue et al., 2017). Our results show that changes in their composition also determine how entire communities respond to environmental change.

Even though they often occur simultaneously, predator loss and other elements of global environmental change, such as warming and eutrophication, are generally investigated independently (Estes et al., 2011). When ecological responses to environmental drivers interact - that is, when their combined effects are either significantly greater (synergistic; Sala \& Knowlton, 2006) or less than (antagonistic; Crain et al., 2008) the sum of their individual effects - predicting their cumulative impacts remains a significant challenge. We found that effects of predators and our experimental perturbations on univariate ecosystem functions - community metabolism, the biomass of algae and grazers, and abundance of meso-invertebrates - were generally additive (i.e. equal to the sum of the individual effects; Vye et al., 2017). This suggests that interactions between multiple stressors may not be a pervasive phenomenon in marine systems (Halpern et al., 2008). In contrast, however, effects on multivariate community composition - on the structure of macroalgal, grazer and mesoinvertebrate assemblages - were consistently interactive across all functional groups (Darling \& Côté, 2008; Greig et al., 2012; Perkins et al., 2015; Mrowicki and O'Connor, 2015). This disparity in responses indicates clearly a greater capacity for multivariate tools to detect interactive impacts of multiple stressors. It likely also reflects greater sensitivity of community composition to the complexities of environmental change, compared to aggregated measures of community productivity or biomass. Moreover, our findings also demonstrate that the individual and combined effects of multiple stressors can be highly unpredictable and inconsistent across trophic levels. This highlights clearly the importance of measuring a variety of response variables (e.g. univariate, multivariate and aggregate measures of ecosystem functioning) and incorporating sufficient trophic complexity (multiple trophic levels, each with multiple functionally distinct species) in global change experiments (Donohue et al., 2013, 2016).

This article is protected by copyright. All rights reserved. 
Indirect effects of predators on algal and invertebrate assemblages were complex and varied with environmental context. Nutrient enrichment did not buffer against a trophic cascade - enrichment did not result in an increase in algal biomass when grazer biomass, and thus grazing pressure, was high owing to lack of predators, despite buffering effects observed previously on rocky intertidal shores (O’Connor \& Donohue, 2013). Rather, nutrient enrichment facilitated predator-driven shifts in algal and grazer assemblage structure, showing that cumulative effects of anthropogenic disturbances, such as predator species loss and nutrient enrichment, can act synergistically (Sala \& Knowlton, 2006; Halpern et al., 2007). In contrast, predator-mediated shifts in meso-invertebrate assemblages occurred only in treatments at ambient temperatures and nutrient concentrations, indicating that these stressors can also act antagonistically (Crain et al., 2008; Jackson et al., 2016), cancelling out the effects of changing predator composition. Another explanation for the observed increases in grazer biomass resulting from predator loss is that our manipulated predators may have indirectly altered foraging rates (and subsequently growth) of their prey, due to predator avoidance behaviours (Trussell et al., 2002; 2003). Considering both direct and indirect non-trophic and trophic interactions (Kefi et al., 2016; Donohue et al., 2017) is, therefore, fundamental to predicting the consequences of species loss and other elements of global change.

We detected stronger effects of nutrient enrichment on intermediate consumers - both mesoinvertebrate and gastropod grazer communities - than on primary producers. Adding nutrients increased abundance of meso-invertebrates and induced predator-driven shifts in grazer assemblages but did not alter algal communities via growth of ephemeral species. The observed lack of algal response to increased nutrient availability supports the idea of trophic compensation, whereby bottom-up effects of environmental stressors can be compensated by increased consumption by consumers, a phenomenon that appears to be common in marine systems (O'Connor \& Bruno, 2007; O’Connor \& Donohue, 2013; Ghedini et al., 2015). However, we did not quantify specific grazing 
rates or algal biomass measures for a procedural control that excluded both predators and grazers and could not, therefore, verify that this occurred in our study. In contrast, enrichment altered grazer assemblages via reducing relative biomass of Patella and Littorina when both predator species were present. This illustrates that trophic compensation could be complicated even further by higher trophic levels and the overall complex nature of trophic interactions. Compensatory dynamics among species may therefore prove crucial in determining the emergent properties of ecological stability and resistance to environmental change at larger spatio-temporal scales (Connell \& Ghedini, 2015; Goldenburg et al., 2018).

The magnitude of warming in our mesocosms was small in comparison to diurnal and seasonal ranges in temperate rock pools (Morris \& Taylor, 1983). Nonetheless, this warming led to significant reductions in macroalgal biomass, as would be expected under high grazing pressure based on universal metabolic responses (O’Connor, 2009). Warming also brought about decreases in gross assemblage productivity over a relatively short time period (eight weeks). Predators altered gross assemblage productivity, with predator polycultures being more productive than any other treatment, supporting the idea that increased diversity can promote ecosystem functioning (Yachi \& Loreau, 1999). However, it remains unclear which mechanisms underpin such increases in productivity, as we found no evidence for any corresponding shifts in algal communities specific to treatments with both predators present. Despite significantly reduced grazer biomass in the presence of predators, especially crabs, algal biomass remained constant regardless of predator composition. It is possible that crabs consumed macroalgae in the absence of gastropod prey (Jochum et al., 2012), thus maintaining similar grazing pressure. The presence of Patella ulyssiponensis has been shown to reduce gross productivity in natural temperate rock pools (Griffin et al., 2010), yet this was also accompanied by a corresponding reduction in algal biomass. We detected idiosyncratic changes in Patella biomass in predator polycultures compared to other predator treatments, which varied with nutrient enrichment making exact mechanisms difficult to disentangle. However, our results highlight that decoupling can occur between algal biomass and gross primary productivity, suggesting that

This article is protected by copyright. All rights reserved. 
shifts in algal biomass should be used as a proxy of productivity with caution (Masterson et al., 2008; Griffin et al., 2010).

In contrast to our results, Antiqueira et al. (2017) found that warming increased productivity and predator loss indirectly increased productivity via increased diversity of detritivorous macroinvertebrates in aquatic bromeliad systems. However, they used a multifunctional approach whereby ecosystem productivity incorporated multiple variables such as ammonium, chlorophyll and

${ }^{15} \mathrm{~N}$ and included elements of nutrient cycling. The oxygen evolution method we used has provided significant insight into ecosystem functioning in both natural and synthetic rockpools (e.g. Nielsen, 2001; Altieri et al., 2009; Griffin et al., 2010; O’Connor et al., 2015; Vye et al., 2015). It has, however, limitations as a proxy for overall ecosystem functioning due to the non-linear contributions of individual functions to multifunctionality (Byrnes et al., 2014a; 2014b). Individual ecosystem functions respond differently to environmental drivers (Jing et al. 2015; Perkins et al. 2015), thus ideally both summary indices and multiple indicators that provide unique information on ecosystem functionality should be measured when investigating the impacts of environmental changes and biodiversity loss.

We found evidence for effects of warming on all three of our functional response groups (i.e. macroalgae, gastropod grazers and meso-invertebrate consumers). However, these effects tended to interact with predator composition and nutrients. Resource partitioning may have occurred between macroalgal species - seaweeds can exhibit differences in nutrient uptake (Bracken and Stachowitz, 2006), in addition to variation in light intensity required for optimum performance (Johansson and Snoeijs, 2002), resulting in changes in competitive dominance. For macroalgal communities, warming inhibited growth of $F$. serratus and M. stellatus, but only in nutrient enriched crab monocultures. This could reflect interspecific differences in physiological tolerances and changes in competition within assemblages in response to both top-down and bottom-up control (Harley et al., 2012). This contrasts

This article is protected by copyright. All rights reserved. 
with previous findings that warming can promote the growth of Fucoids at the expense of other macroalgal species (Mrowicki \& O'Connor, 2015), although this effect was moderated by wave action, which further highlights the importance of environmental context for global change experiments. Although changes in algal assemblage structure may maintain total biomass and primary productivity at similar levels, different species are rarely multifunctionally equivalent, thus true compensation cannot be assumed (Bruno et al., 2005; O'Connor \& Bruno, 2007). Furthermore, tradeoffs exist such that net primary productivity may vary with palatability of algal species (Bruno et al., 2005; Griffin et al., 2009b), with knock-on consequences for secondary production as a result of trophic preference. In contrast to previous mesocosm experiments (Staehr \& Sand-Jensen, 2006), we found no evidence for interactions between warming and nutrient enrichment on assemblage productivity, and no scenarios where the effects of one of those cancelled out the effects of the other (McElroy et al., 2015). Regardless of mechanisms, our findings demonstrate that effects of ocean warming on coastal communities are likely to be widespread across functional groups and may be further complicated by top-down effects of predators as well as predicted increases in eutrophication events.

To reflect the structure of natural communities on local rocky shores, we kept predator density consistent and did not compensate for differences in biomass.

Whelks and crabs differ significantly in biomass of individuals and feeding preferences (Little, Williams \& Trowbridge, 2009). Their presence is thus likely to affect different parts of the food web [e.g. crabs eat limpets (Silva et al., 2008), key grazers in this system (O'Connor \& Crowe, 2005, Coleman et al., 2006), whereas whelks less so]. As such, we would have had to supplement with high numbers of whelks at unnatural densities. Further, biomass compensation has its own associated disadvantages - replacement experiments can conflate reductions in intraspecific interactions with increases in interspecific interactions (Byrnes \& Stachowicz, 2009). However, unbalanced top-down control is a potential driver for the observed reductions in gastropod biomass in our experiment,

This article is protected by copyright. All rights reserved. 
driven by predator biomass and associated energetic demands (Brown et al., 2004). Meso-invertebrate abundance was not reduced by presence of crabs and whelks in combination, despite being reduced in predator monocultures. This is suggestive of competitive interactions between predator species independent of their biomass. We had just two levels of each stressor treatment (ambient and warmed temperatures, ambient and enriched nutrient concentrations) owing to the logistical constraints of testing a relatively large number of experimental treatments. This limited the types of interactions that could be revealed by our experiment. In spite of their inherent complexity, it is apparent that intensity (Vye et al., 2015) and variability (García Molinos \& Donohue, 2010; García Molinos \& Donohue, 2011) of multiple stressors can alter their impacts on the structure and functioning of biotic communities. Exploring and integrating these effects must be a priority for research in the future

Despite the clear importance of global environmental change and disproportionately large risk of predator diversity loss, we know little about their cumulative direct and indirect impacts on marine communities. Expanding our knowledge of the mechanisms underpinning community level change is essential both to predict and manage for their combined effects in a changing world. Our results demonstrate that predators can alter both the individual and combined effects of warming and nutrient enrichment both synergistically and antagonistically and, moreover, that all of these anthropogenic disturbances can also act independently on different components of a marine community. Changes in biodiversity - and loss of predators in particular - can play an important role in moderating the capacity of communities to resist and respond to environmental change. Our forecasting ability depends not only the level of ecological complexity (e.g. the number of trophic levels and functional groups) incorporated within global change experiments, but also on the tools (e.g. multivariate vs. univariate approaches) ecologists use to detect changes in community dynamics.

This article is protected by copyright. All rights reserved. 


\section{Acknowledgements}

We thank John Griffin, Ian Montgomery and two anonymous reviewers for their insightful comments, which helped to improve the quality of this manuscript. We are grateful to A. Gilson, C. Bertolini, L. Eagling, N. Phillips, E. Gorman and B. McNamara for their assistance with experimental work. This study was completed as part of a PhD studentship funded by the Department for Economy Northern Ireland.

\section{References}

Airoldi, L., \& Beck, M. W. (2007). Loss, status and trends for coastal marine habitats of Europe. Oceanography and Marine Biology, 45, 345-405.

Airoldi, L., Balata, D., \& Beck, M. W. (2008). The Gray Zone: Relationships between habitat loss and marine diversity and their applications in conservation. Journal of Experimental Marine Biology and Ecology, 366, 8-15.

Allen, A. P., Gillooly, J. F., \& Brown, J. H. (2005). Linking the global carbon cycle to individual metabolism. Functional Ecology, 19, 202-213.

Alsterberg, C., Eklöf, J. S., Gamfeldt, L., Havenhand, J. N., \& Sundbäck, K. (2013). Consumers mediate the effects of experimental ocean acidification and warming on primary producers. Proceedings of the National Academy of Sciences, 110, 8603-8.

Altieri, A. H., Trussell, G. C., Ewanchuk, P. J., Bernatchez, G., \& Bracken, M. E. S. (2009). Consumers Control Diversity and Functioning of a Natural Marine Ecosystem. PLoS ONE, 4, $21-23$.

Anderson, M. J. (2001). A new method for non-parametric multivariate analysis of variance. Austral Ecology, 26, 32-46.

This article is protected by copyright. All rights reserved. 
Anderson, M. J. (2006) Distance-based tests for homogeneity of multivariate Dispersions. Biometrics, $62,245-253$.

Antiqueira, P. A. P., Petchey, O. L., \& Romero, G. Q. (2017). Warming and top predator loss drive ecosystem multifunctionality. Ecology Letters, 21, 72-82.

Antón, A., Cebrian, J., Duarte, C. M., Jr, K. L. H., \& Goff, J. (2009). Low impact of Hurricane Katrina on seagrass community structure and functioning in the northern Gulf of Mexico. Bulletin of Marine Science, 85, 45-59.

Antón, A., Cebrian, J., Heck, K. L., Duarte, C. M., Sheehan, K. L., Miller, M.-E. C., \& Foster, C. D. (2011). Decoupled effects (positive to negative) of nutrient enrichment on ecosystem services. Ecological Applications, 21, 991-1009.

Arenas, F., Rey, F., \& Pinto, I. S. (2009). Diversity effects beyond species richness: Evidence from intertidal macroalgal assemblages. Marine Ecology Progress Series, 381, 99-108.

Baum, J. K., \& Worm, B. (2009). Cascading top-down effects of changing oceanic predator abundances. Journal of Animal Ecology, 78, 699-714.

Benton, T. G., Solan, M., Travis, J. M. J., \& Sait, S. M. (2007). Microcosm experiments can inform global ecological problems. Trends in Ecology and Evolution, 22, 516-521.

Blake, R. E., \& Duffy, J. E. (2010). Grazer diversity affects resistance to multiple stressors in an experimental seagrass ecosystem. Oikos, 119, 1625-1635.

Blake, R. E., \& Duffy, J. E. (2012). Changes in biodiversity and environmental stressors influence community structure of an experimental eelgrass Zostera marina system. Marine Ecology Progress Series, 470, 41-54.

Bracken, M. E. S., \& Stachowicz, J. J. (2006). Seaweed diversity enhances nitrogen uptake via complementary use of nitrate and ammonium. Ecology, 87, 2397-2403.

Britten, G. L., Dowd, M., Minto, C., Ferretti, F., Boero, F., \& Lotze, H. K. (2014). Predator decline

This article is protected by copyright. All rights reserved. 
leads to decreased stability in a coastal fish community. Ecology Letters, 17, 1518-1525.

Brown, J. H., Gillooly, J. F., Allen, A. P., Savage, V. M., \& West, G. B. (2004). Toward a metabolic theory of ecology. Ecology, 85, 1771-1789.

Bruno, J. F., Boyer, K. E., Duffy, J. E., Lee, S. C., \& Kertesz, J. S. (2005). Effects of macroalgal species identity and richness on primary production in benthic marine communities. Ecology Letters, 8, 1165-1174.

Bruno, J. F., \& O'Connor, M. I. (2005). Cascading effects of predator diversity and omnivory in a marine food web. Ecology Letters, 8, 1048-1056.

Byrnes, J. E., \& Stachowicz, J. J. (2009). The consequences of consumer diversity loss: Different answers from different experimental designs. Ecology, 90, 2879-2888.

Byrnes, J. E. K., Gamfeldt, L., Isbell, F., Lefcheck, J. S., Griffin, J. N., Hector, A., ... Emmett Duffy, J. (2014a). Investigating the relationship between biodiversity and ecosystem multifunctionality: Challenges and solutions. Methods in Ecology and Evolution, 5, 111-124.

Byrnes, J., Lefcheck, J. S., Gamfeldt, L., Griffin, J. N., Isbell, F., \& Hector, A. (2014b). Multifunctionality does not imply that all functions are positively correlated. Proceedings of the National Academy of Sciences, 111, E5490

Canning-Clode, J., Kaufmann, M., Molis, M., Wahl, M., \& Lenz, M. (2008). Influence of disturbance and nutrient enrichment on early successional fouling communities in an oligotrophic marine system. Marine Ecology, 29, 115-124.

Clarke, K. R., \& Warwick, R. M. (2001). Change in marine communities: an approach to statistical analysis and interpretation. PRIMER-E:Plymouth.

Coleman, R. A., Underwood, A. J., Benedetti-Cecchi, L., Åberg, P., Arenas, F., Arrontes, J., Castro, J., Hartnoll, R.G., Jenkins, S.R., Paula, J., Della Santina, P. \& Hawkins, S. J. (2006). A continental scale evaluation of the role of limpet grazing on rocky shores. Oecologia, 147, 556-

This article is protected by copyright. All rights reserved. 
564.

Connell, J. H. (1972). Community Interactions on Marine Rocky Intertidal Shores. Annual Review of Ecology and Systematics, 3, 169-192.

Connell, S. D., \& Ghedini, G. (2015). Resisting regime-shifts : the stabilising effect of compensatory processes. Trends in Ecology \& Evolution, 30, 1-3.

Côté, I. M., Darling, E. S., \& Brown, C. J. (2016). Interactions among ecosystem stressors and their importance in conservation. Proceedings of the Royal Society B: Biological Sciences, 283, 20152592.

Crain, C. M., Kroeker, K., \& Halpern, B. S. (2008). Interactive and cumulative effects of multiple human stressors in marine systems. Ecology Letters, 11, 1304-1315.

Darling, E. S., \& Côté, I. M. (2008). Quantifying the evidence for ecological synergies. Ecology Letters, 11, 1278-1286.

Donohue, I., Petchey, O. L., Kéfi, S., Génin, A., Jackson, A. L., Yang, Q., \& O’Connor, N. E. (2017). Loss of predator species, not intermediate consumers, triggers rapid and dramatic extinction cascades. Global Change Biology, 23, 2962-2972.

Duffy, J. E. (2002). Biodiversity and ecosystem function: The consumer connection. Oikos, 99, 201219.

Eklöf, J. S., Alsterberg, C., Havenhand, J. N., Sundbäck, K., Wood, H. L., \& Gamfeldt, L. (2012). Experimental climate change weakens the insurance effect of biodiversity. Ecology Letters, 15, 864-872.

Estes, J. A., Terborgh, J., Brashares, J. S., Power, M. E., Berger, J., Bond, W. J., ... Wardle, D. A. (2011). Trophic Downgrading of Planet Earth. Science, 333, 301-306.

García Molinos, J., \& Donohue, I. (2010). Interactions among temporal patterns determine the effects of multiple stressors. Ecological Applications, 20, 1794-1800.

This article is protected by copyright. All rights reserved. 
García Molinos, J., \& Donohue, I. (2011). Temporal variability within disturbance events regulates their effects on natural communities. Oecologia, 166, 795-806.

Garnier, A., Pennekamp, F., Lemoine, M., \& Petchey, O. L. (2017). Temporal scale dependent interactions between multiple environmental disturbances in microcosm ecosystems. Global Change Biology, 23, 5237-5248.

Ghedini, G., \& Connell, S. D. (2016). Organismal homeostasis buffers the effects of abiotic change on community dynamics. Ecology, 97, 2671-2679.

Ghedini, G., Russell, B. D., \& Connell, S. D. (2015). Trophic compensation reinforces resistance : herbivory absorbs the increasing effects of multiple disturbances. Ecology Letters, 18, 182-187.

Goldenberg, S. U., Nagelkerken, I., Marangon, E., Bonnet, A., Ferreira, C. M., \& Connell, S. D. (2018). Ecological complexity buffers the impacts of future climate on marine consumers. Nature Climate Change, 8, 229-233.

Greig, H. S., Kratina, P., Thompson, P. L., Palen, W. J., Richardson, J. S., \& Shurin, J. B. (2012). Warming, eutrophication, and predator loss amplify subsidies between aquatic and terrestrial ecosystems. Global Change Biology, 18, 504-514.

Griffin, J. N., Jenkins, S. R., Gamfeldt, L., Jones, D., Hawkins, S. J., \& Thompson, R. C. (2009a). Spatial heterogeneity increases the importance of species richness for an ecosystem process. Oikos, 118, 1335-1342.

Griffin, J. N., Mendez, V., Johnson, A. F., Jenkins, S. R. \& Foggo, A. (2009b) Functional diversity predicts overyielding effect of species combination on primary productivity. Oikos, 118, 37-44.

Griffin, J. N., Noël, L. M. L. J., Crowe, T. P., Burrows, M. T., Hawkins, S. J., Thompson, R. C., \& Jenkins, S. R. (2010). Consumer effects on ecosystem functioning in rock pools: Roles of species richness and composition. Marine Ecology Progress Series, 420, 45-56.

Griffin, J. N., \& Silliman, B. R. (2011). Predator diversity stabilizes and strengthens trophic control of

This article is protected by copyright. All rights reserved. 
a keystone grazer. Biology Letters, 7, 79-82.

Gunderson, A. R., Armstrong, E. J., \& Stillman, J. H. (2016). Multiple Stressors in a Changing World: The Need for an Improved Perspective on Physiological Responses to the Dynamic Marine Environment. Annual Review of Marine Science, 87, 357-78.

Gruner, D. S., Bracken, M. E. S., Berger, S. A., Eriksson, B. K., Gamfeldt, L., Matthiessen, B., ... Hillebrand, H. (2017). Effects of experimental warming on biodiversity depend on ecosystem type and local species composition. Oikos, 126, 8-17.

Halpern, B. S., Selkoe, K. A., Micheli, F., \& Kappel, C. V. (2007). Evaluating and ranking the vulnerability of global marine ecosystems to anthropogenic threats. Conservation Biology, 21, $1301-1315$.

Halpern, B. S., Walbridge, S., Selkoe, K. A., Kappel, C. V., Micheli, F., D’Agrosa, C., ... Watson, R. (2008). A Global Map of Human Impact on Marine Ecosystems. Science, 319, 948-952.

Harley, C. D. G., Hughes, a. R., Hultgren, K. M., Miner, B. G., Sorte, C. J. B., Thornber, C. S., ... Williams, S. L. (2006). The impacts of climate change in coastal marine systems. Ecology Letters, 9, 228-241.

Harley, C. D. G., Anderson, K. M., Demes, K. W., Jorve, J. P., Kordas, R. L., Coyle, T. A., \& Graham, M. H. (2012). EFfects Of Climate Change On Global Seaweed Communities. Journal of Phycology, 48, 1064-1078.

Harley, C. D. G., Connell, S. D., Doubleday, Z. A., Kelaher, B., Russell, B. D., Sarà, G., \& Helmuth, B. (2017). Conceptualizing ecosystem tipping points within a physiological framework. Ecology and Evolution, 7, 6035-6045.

Hawkins, S. J., Gibbs, P. E., Pope, N. D., Burt, G. R., Chesman, B. S., Bray, S., ... Spence, S. K. (2002). Recovery of polluted ecosystems : the case for long-term studies. Marine Environmental Research, 54, 215-222.

This article is protected by copyright. All rights reserved. 
Hawkins, S. J. (1981). The influence of season and barnacles on algal colonisation of Patella vulgata L. exclusion areas. Journal of the Marine Biological Association of the United Kingdom, 61, 115.

Helmuth, B., Broitman, B. R., Blanchette, C., Gilman, S., Halpin, P., Harley, C. D., ... Strickland, D. (2006). Mosaic patterns of thermal stress in the rocky intertidal zone: Implications for climate change. Ecological Monographs, 76, 461-479.

Hooper, D. U., Adair, E. C., Cardinale, B. J., Byrnes, J. E. K., Hungate, B. A., Matulich, K. L., ... Connor, M. I. O. (2012). A global synthesis reveals biodiversity loss as a major driver of ecosystem change. Nature, 486, 105-108.

Hughes, R. N., \& Elner, R. W. (1979). Tactics of a Predator, Carcinus Maenas, and Morphological Responses of the Prey, Nucella Lapillus. Journal of Animal Ecology, 48, 65-78.

Hulme, M., Jenkins, G. J., Lu, X., Turnpenny, J. R., Mitchell, T. D., Jones, R. G., ... Hill, S. (2002). Climate Change Scenarios for the United Kingdom: The UKCIP02 Scientific Report. Tyndall Centre for Climate Change Research, School of Environmental Sciences, University of East Anglia, Norwich, UK.

Jenkins, S. R., Coleman, R. A., Della Santina, P., Hawkins, S. J., Burrows, M. T., \& Hartnoll, R. G. (2005). Regional scale differences in the determinism of grazing effects in the rocky intertidal. Marine Ecology Progress Series, 287, 77-86.

Jing, X., Sanders, N. J., Shi, Y., Chu, H., Classen, A. T., Zhao, K., ... He, J.-S. (2015). The links between ecosystem multifunctionality and above- and belowground biodiversity are mediated by climate. Nature Communications, 6, 8159.

Jochum, M., Schneider, F. D., Crowe, T. P., Brose, U., \& O’Gorman, E. J. (2012). Climate-induced changes in bottom-up and top-down processes independently alter a marine ecosystem. Philosophical Transactions of the Royal Society B: Biological Sciences, 367, 2962-2970.

This article is protected by copyright. All rights reserved. 
Johansson, G., \& Snoeijs, P. (2002). Macroalgal photosynthetic responses to light in relation to thallus morphology and depth zonation. Marine Ecology Progress Series, 244, 63-72.

Jöhnk, K. D., Huisman, J., Sharples, J., Sommeijer, B., Visser, P. M., \& Stroom, J. M. (2008). Summer heatwaves promote blooms of harmful cyanobacteria. Global Change Biology, 14, $495-512$.

Kéfi, S., Miele, V., Wieters, E. A., Navarrete, S. A., \& Berlow, E. L. (2016). How Structured Is the Entangled Bank? The Surprisingly Simple Organization of Multiplex Ecological Networks Leads to Increased Persistence and Resilience. PLoS Biology, 14, 1-21

Kordas, R. L., Harley, C. D. G., \& O’Connor, M. I. (2011). Community ecology in a warming world: The influence of temperature on interspecific interactions in marine systems. Journal of Experimental Marine Biology and Ecology, 400, 218-226

Kordas, R. L., Donohue, I., \& Harley, C. D. G. (2017). Herbivory enables marine communities to resist warming. Science Advances, 3, e1701349.

Kratina, P., Greig, H., Thompson, P., Carvalho-Pereira, T., \& Shurin, J. (2012). Warming modifies trophic cascades and eutrophication in experimental freshwater communities. Ecology, 93, $1421-1430$.

Lotze, H. K., Lenihan, H. S., Bourque, B. J., Bradbury, R. H., Cooke, R. G., Kay, M. C., ... Jackson, J. B. C. (2006). Depletion, Degradation, and Recovery Potential of Estuaries and Coastal Seas. Science, 312, 1806-1809.

Masterson, P., Arenas, F. A., Thompson, R. C., \& Jenkins, S. R. (2008). Interaction of top down and bottom up factors in intertidal rockpools: Effects on early successional macroalgal community composition, abundance and productivity. Journal of Experimental Marine Biology and Ecology, 363, 12-20.

Matias, M. G., Underwood, A. J., Hochull, D. F., \& Coleman, R. A. (2010). Independent effects of

This article is protected by copyright. All rights reserved. 
patch size and structural complexity on diversity of benthic macroinvertebrates. Ecology, 91, 1908-1915.

McArdle, B. H., Anderson, M. J., Ecology, S., \& Jan, N. (2001). Fitting Multivariate Models to Community Data: A Comment on Distance-Based Redundancy Analysis. Ecology, 82, 290297.

McClean, D., McNally, L., Salzberg, L.I., Devine, K.M., Brown, S.P. \& Donohue, I. (2015) Single gene locus changes perturb complex microbial communities as much as apex predator loss. Nature Communications, 6, 8235.

McElroy, D. J., O’Gorman, E. J., Schneider, F. D., Hetjens, H., Le Merrer, P., Coleman, R. A., \& Emmerson, M. (2015). Size-balanced community reorganization in response to nutrients and warming. Global Change Biology, 21, 3971-3981.

Mckee, D., Hatton, K., Eaton, J. W., Atkinson, D., Atherton, A., Harvey, I., \& Moss, B. (2002). Effects of simulated climate warming on macrophytes in freshwater microcosm communities. Aquatic Botany, 74, 71-83.

Menge, B. A., \& Sutherland, J. P. (1987). Community Regulation: Variation in Disturbance, Competition, and Predation in Relation to Environmental Stress and Recruitment. The American Naturalist, 130, 730-757.

Mieszkowska, N., Kendall, M. A., Hawkins, S. J., Leaper, R., Williamson, P., Hardman-Mountford, N. J., \& Southward, A. J. (2006). Changes in the range of some common rocky shore species in Britain - A response to climate change? Hydrobiologia, 555, 241-251.

Monaco, C. J., \& Helmuth, B. (2011). Tipping Points, Thresholds and the Keystone Role of Physiology in Marine Climate Change Research. Advances in Marine Biology, 60, 123-160

Morris, S., \& Taylor, A. C. (1983). Diurnal and seasonal variation in physico-chemical conditions within intertidal rock pools. Estuarine, Coastal and Shelf Science, 17, 339-355.

This article is protected by copyright. All rights reserved. 
Mrowicki, R. J., \& O’Connor, N. E. (2015). Wave action modifies the effects of consumer diversity and warming on algal assemblages. Ecology, 96, 1020-1029.

Mrowicki, R. J., O'Connor, N. E., \& Donohue, I. (2016). Temporal variability of a single population can determine the vulnerability of communities to perturbations. Journal of Ecology, 104, 887897.

Nash, K. L., Cvitanovic, C., Fulton, E. A., Halpern, B. S., Milner-Gulland, E. J., Watson, R. A., \& Blanchard, J. L. (2017). Planetary boundaries for a blue planet. Nature Ecology and Evolution, $1,1625-1634$.

Nemani, R. R. (2003). Climate-Driven Increases in Global Terrestrial Net Primary Production from 1982 to 1999. Science, $300,1560-1563$.

Nielsen, K. J. (2001). Bottom-Up and Top-Down Forces in Tide Pools: Test of a Food Chain Model in an Intertidal Community. Ecological Monographs, 71, 187-217.

Noël, L. M. L. J., Griffin, J. N., Thompson, R. C., Hawkins, S. J., Burrows, M. T., Crowe, T. P., \& Jenkins, S. R. (2010). Assessment of a field incubation method estimating primary productivity in rockpool communities. Estuarine, Coastal and Shelf Science, 88, 153-159.

O’Connor, M. I. (2009). Warming Strengthens an Herbivore: Plant Interaction. Ecology, 90, 388-398.

O’Connor, M. I., Piehler, M. F., Leech, D. M., Anton, A., \& Bruno, J. F. (2009). Warming and resource availability shift food web structure and metabolism. PLoS Biology, 7, 3-8.

O’Connor, N. E., Bracken, M. E., Crowe, T. P., \& Donohue, I. (2015). Nutrient enrichment alters the consequences of species loss. Journal of Ecology, 103, 862-870.

O'Connor, N. E., \& Bruno, J. F. (2007). Predatory fish loss affects the structure and functioning of a model marine food web. Oikos, 116, 2027-2038.

O’Connor, N. E., \& Donohue, I. (2013). Environmental context determines multi-trophic effects of consumer species loss. Global Change Biology, 19, 431-440.

This article is protected by copyright. All rights reserved. 
O’Connor, N. E., Emmerson, M. C., Crowe, T. P., \& Donohue, I. (2013). Distinguishing between direct and indirect effects of predators in complex ecosystems. Journal of Animal Ecology, 82, $438-448$.

O'Gorman, E. J., Enright, R. A., \& Emmerson, M. C. (2008). Predator diversity enhances secondary production and decreases the likelihood of trophic cascades. Oecologia, 158, 557-567.

O'Gorman, E. J., Fitch, J. E., \& Crowe, T. P. (2012). Multiple anthropogenic stressors and the structural properties of food webs. Ecology, 93, 441-448.

O’Gorman, E. J., Jacob, U., Jonsson, T., \& Emmerson, M. C. (2010). Interaction strength, food web topology and the relative importance of species in food webs. Journal of Animal Ecology, 79, 682-692.

Padilla-Gamiño, J. L., \& Carpenter, R. C. (2007). Seasonal acclimatization of Asparagopsis taxiformis (Rhodophyta) from different biogeographic regions. Limnology and Oceanography, $52,833-842$.

Perkins, D. M., Bailey, R. A., Dossena, M., Gamfeldt, L., Reiss, J., Trimmer, M., \& Woodward, G. (2015). Higher biodiversity is required to sustain multiple ecosystem processes across temperature regimes. Global Change Biology, 21, 396-406.

Petchey, O. L., McPhearson, P. T., Casey, T. M., \& Morin, P. J. (1999). Environmental warming alters food-web structure and ecosystem function. Nature, 402, 69-72.

Pimm, S. L. (1984). The complexity and stability of ecosystems. Nature, 307, 321-326.

R Development Core Team, R. (2017). R: A Language and Environment for Statistical Computing. Vienna, Austria: R Foundation for Statistical Computing, URL http://www.R-project.org/.

Rangeley, R. W., \& Thomas, M. L. H. (1987). Predatory behaviour of juvenile shore crab Carcinus maenas (L.). Journal of Experimental Marine Biology and Ecology, 108, 191-197.

Sala, E., \& Knowlton, N. (2006). Global Marine Biodiversity Trends. Annual Review of Environment

This article is protected by copyright. All rights reserved. 
and Resources, 31, 93-122.

Sampaio, E., Rodil, I. F., Vaz-Pinto, F., Fernández, A., \& Arenas, F. (2017). Interaction strength between different grazers and macroalgae mediated by ocean acidification over warming gradients. Marine Environmental Research, 125, 25-33.

Sanford, E. (1999). Regulation of Keystone Predation by Small Changes in Ocean Temperature. Science, 283, 2095-2097.

Shurin, J. B., Clasen, J. L., Greig, H. S., Kratina, P., \& Thompson, P. L. (2012). Warming shifts topdown and bottom-up control of pond food web structure and function. Philosophical Transactions of the Royal Society B: Biological Sciences, 367, 3008-3017

Sheehan, E. V, Coleman, R. A., Thompson, R. C., \& Attrill, M. J. (2010). Crab-tiling reduces the diversity of estuarine infauna, 411, 137-148.

Silva, A. C. F., Hawkins, S. J., Boaventura, D. M., \& Thompson, R. C. (2008). Predation by small mobile aquatic predators regulates populations of the intertidal limpet Patella vulgata (L.). Journal of Experimental Marine Biology and Ecology, 367, 259-265.

Sinha, E., Michalak, A. M., \& Balaji, V. (2017). Eutrophication will increase during the 21st century as a result of precipitation changes. Science, 357, 405-408.

Smale, D. A., Taylor, J. D., Coombs, S. H., Moore, G., \& Cunliffe, M. (2017). Community responses to seawater warming are conserved across diverse biological groupings and taxonomic resolutions. Proceedings of the Royal Society B: Biological Sciences, 284, 20170534.

Smith, V. H., Tilman, G. D., \& Nekola, J. C. (1999). Eutrophication: Impacts of excess nutrient inputs on freshwater, marine, and terrestrial ecosystems. Environmental Pollution, 100, 179-196.

Staehr, A. P., \& Sand-Jensen, K. (2006). Seasonal changes in temperature and nutrient control of photosynthesis, respiration and growth of natural phytoplankton communities. Freshwater Biology, 51, 249-262.

This article is protected by copyright. All rights reserved. 
Stewart, F. R. I. A., Dossena, M., Bohan, D. A., Jeppesen, E., Kordas, R. L., Ledger, M. E., ...

Trimmer, M. (2013). Mesocosm Experiments as a Tool for Ecological Climate-Change. Global Change in Multispecies Systems: Part III (1st ed., Vol. 48). Elsevier Ltd.

Stutes, J., Cebrian, J., Stutes, A. L., Hunter, A., \& Corcoran, A. A. (2007). Benthic metabolism across a gradient of anthropogenic impact in three shallow coastal lagoons in NW Florida. Marine Ecology Progress Series, 348, 55-70.

Sugden, H., Lenz, M., Molis, M., Wahl, M., \& Thomason, J. C. (2008). The interaction between nutrient availability and disturbance frequency on the diversity of benthic marine communities on the north-east coast of England. Journal of Animal Ecology, 77, 24-31.

Terborgh, J., Lopez, L., Nun, P., Rao, M., Shahabuddin, G., Orihuela, G., ... Balbas, L. (2001). Ecological Meltdown in Predator-Free Forest Fragments. Science, 294, 1923-1927.

Thompson, R. C., Crowe, T. P., \& Hawkins, S. J. (2002). Rocky intertidal communities: past environmental changes, present status and predictions for the next 25 years. Environmental Conservation, 29, 168-191.

Trussell, G. C., Ewanchuk, P. J., \& Bertness, M. D. (2002). Field evidence of trait-mediated indirect interactions in a rocky intertidal food web. Ecology Letters, 5, 241-245

Trussell, G. C., Ewanchuk, P. J., \& Bertness, M. D. (2003). Trait-Mediated Effects in Rocky Intertidal Food Chains: Predator Risk Cues Alter Prey Feeding Rates. Ecology, 84, 629-640.

Vye, S. R., Emmerson, M. C., Arenas, F., Dick, J. T. A., \& O'Connor, N. E. (2015). Stressor intensity determines antagonistic interactions between species invasion and multiple stressor effects on ecosystem functioning. Oikos, 124, 1005-1012.

Vye, S., Emmerson, M. C., Dick, J. T. A., \& O’Connor, N. E. (2017). Cumulative effects of multiple stressors: An invasive oyster and nutrient enrichment reduce subsequent invasive barnacle recruitment. Journal of Experimental Marine Biology and Ecology, 486, 322-327.

This article is protected by copyright. All rights reserved. 
Vye, S., Dick, J. T. A., Emmerson, M. C., \& O'Connor, N. E. (2018). Cumulative effects of an invasive species and nutrient enrichment on rock pool communities. Marine Ecology Progress Series, 594, 39-50.

Worm, B., Barbier, E. B., Beaumont, N. J., Duffy, J. E., Folke, C., Halpern, B. S., ... Watson, R. (2006). Impacts of biodiversity loss on ocean ecosystem services. Science, 314, 787-90.

Worm, B., Reusch, T. B. H., \& Lotze, H. K. (2000). In situ nutrient enrichment: Methods for marine benthic ecology. International Review of Hydrobiology, 85, 359-375.

Yachi, S., \& Loreau, M. (1999). Biodiversity and ecosystem productivity in a fluctuating environment: The insurance hypothesis. Proceedings of the National Academy of Sciences, 96, $1463-1468$.

Yvon-Durocher, G., \& Allen, A. P. (2012). Linking community size structure and ecosystem functioning using metabolic theory. Philosophical Transactions of the Royal Society B: Biological Sciences, 367, 2998-3007.

Yvon-Durocher, G., Jones, J. I., Trimmer, M., Woodward, G., \& Montoya, J. M. (2010). Warming alters the metabolic balance of ecosystems. Philosophical Transactions of the Royal Society B: Biological Sciences, 365, 2117-2126.

This article is protected by copyright. All rights reserved. 


\section{Tables}

Table 1. The effects (ANOVA) of predator composition, nutrient enrichment and warming on the total biomass (macroalgae, grazers) / abundance (meso-invertebrates) of (a) macroalgae, (b) gastropod grazers and (c) meso-invertebrates. Significant $(P<0.05)$ terms are highlighted in bold.

Source of variation

DF MS

MS

F P

MS

$P$

\begin{tabular}{|c|c|c|c|c|c|c|c|c|c|c|}
\hline Predators, $\mathbf{P}$ & 3 & 0.09 & 2.56 & 0.063 & 1408481 & 18.82 & $<0.001$ & 1.40 & 4.26 & 0.008 \\
\hline Nutrients, $\mathbf{N}$ & 1 & 0.02 & 0.67 & 0.42 & 6171 & 0.08 & 0.78 & 1.69 & 5.12 & 0.027 \\
\hline Warming, W & 1 & 0.27 & 7.23 & 0.009 & 0 & 0.00 & 1 & 1.29 & 3.90 & 0.052 \\
\hline $\mathbf{P} \times \mathbf{N}$ & 3 & 0.01 & 0.22 & 0.89 & 142158 & 1.90 & 0.14 & 0.18 & 0.55 & 0.65 \\
\hline $\mathbf{P} \times \mathbf{W}$ & 3 & 0.08 & 2.17 & 0.1 & 45226 & 0.60 & 0.62 & 0.73 & 2.20 & 0.097 \\
\hline $\mathbf{N} \times \mathbf{W}$ & 1 & 0.01 & 0.38 & 0.54 & 238102 & 3.18 & 0.079 & 0.06 & 0.18 & 0.67 \\
\hline $\mathbf{P} \times \mathbf{N} \times \mathbf{W}$ & 3 & 0.07 & 1.82 & 0.15 & 16778 & 0.22 & 0.88 & 0.61 & 1.84 & 0.15 \\
\hline Residual & 64 & 0.04 & & & 74822 & & & 0.33 & & \\
\hline
\end{tabular}

This article is protected by copyright. All rights reserved. 
Table 2. The effects (PERMANOVA) of predator composition, nutrient enrichment and warming on the assemblage structure of (a) macroalgae, (b) gastropod grazers and (c) mesoinvertebrates. Significant $(P<0.05)$ terms are highlighted in bold.

\begin{tabular}{|c|c|c|c|c|c|c|c|c|c|c|}
\hline \multirow[b]{2}{*}{ Source of variation } & \multirow[b]{2}{*}{ DF } & \multicolumn{3}{|c|}{ (a) Macroalgae } & \multicolumn{3}{|c|}{ (b) Grazers } & \multicolumn{3}{|c|}{ (c) Meso-invertebrates } \\
\hline & & MS & Pseudo- $F$ & $P$ & MS & Pseudo- $F$ & $P$ & MS & Pseudo- $F$ & $P$ \\
\hline Predators, $\mathbf{P}$ & 3 & 538.1 & 2.41 & 0.015 & 881.2 & 1.98 & 0.055 & 2554 & 2.95 & 0.003 \\
\hline Nutrients, $\mathbf{N}$ & 1 & 333.8 & 1.49 & 0.21 & 1673 & 3.76 & 0.011 & 4052 & 4.69 & 0.004 \\
\hline Warming, W & 1 & 690.1 & 3.09 & 0.029 & 256.9 & 0.57 & 0.61 & 3836 & 4.44 & 0.004 \\
\hline $\mathbf{P} \times \mathbf{N}$ & 3 & 313.9 & 1.40 & 0.19 & 1174 & 2.63 & 0.007 & 542.1 & 0.62 & 0.81 \\
\hline $\mathbf{P} \times \mathbf{W}$ & 3 & 363.9 & 1.63 & 0.11 & 227.9 & 0.51 & 0.81 & 938.5 & 1.08 & 0.36 \\
\hline $\mathbf{N} \times \mathbf{W}$ & 1 & 110.0 & 0.49 & 0.70 & -71.1 & 0 & 1 & 353.2 & 0.40 & 0.82 \\
\hline $\mathbf{P} \times \mathbf{N} \times \mathbf{W}$ & 3 & 608.7 & 2.73 & 0.008 & 237.2 & 0.53 & 0.80 & 1970 & 2.28 & 0.018 \\
\hline Residual & 64 & 222.9 & & & 444.7 & & & 863.6 & & \\
\hline
\end{tabular}

This article is protected by copyright. All rights reserved. 
Table 3. Effects (ANOVA) of predator composition, nutrient enrichment and warming on (a) gross assemblage productivity, (b) assemblage respiration, and (c) net assemblage productivity. Significant $(P<0.05)$ terms are highlighted in bold.

\begin{tabular}{|c|c|c|c|c|c|c|c|c|c|c|}
\hline \multirow[b]{2}{*}{ Source of variation } & \multirow[b]{2}{*}{ DF } & \multicolumn{3}{|c|}{ (a) Gross productivity } & \multirow[b]{2}{*}{ MS } & \multicolumn{2}{|c|}{ b) Respiration } & \multicolumn{3}{|c|}{ (c) Net productivity } \\
\hline & & MS & $F$ & $P$ & & $F$ & $P$ & MS & $F$ & $P$ \\
\hline Predators, $\mathbf{P}$ & 3 & 1.18 & 4.69 & 0.005 & 0.74 & 9.57 & $<0.001$ & 0.57 & 4.34 & 0.007 \\
\hline Nutrients, $\mathbf{N}$ & 1 & 0.32 & 1.26 & 0.27 & 0.029 & 0.38 & 0.54 & 0.15 & 1.17 & 0.28 \\
\hline Warming, W & 1 & 0.86 & 3.42 & 0.048 & 4.65 & 59.79 & $<0.001$ & 9.52 & 72.37 & $<0.001$ \\
\hline $\mathbf{P} \times \mathbf{N}$ & 3 & 0.11 & 0.45 & 0.72 & 0.068 & 0.88 & 0.46 & 0.08 & 0.63 & 0.6 \\
\hline $\mathbf{P} \times \mathbf{W}$ & 3 & 0.17 & 0.66 & 0.58 & 0.12 & 1.51 & 0.22 & 0.09 & 0.66 & 0.58 \\
\hline $\mathbf{N} \times \mathbf{W}$ & 1 & 0.46 & 1.81 & 0.18 & 0.27 & 3.44 & 0.068 & 0.03 & 0.19 & 0.66 \\
\hline$P \times N \times W$ & 3 & 0.08 & 0.32 & 0.81 & 0.06 & 0.81 & 0.49 & 0.25 & 1.92 & 0.14 \\
\hline Residual & 64 & 0.25 & & & 0.08 & & & 0.13 & & \\
\hline
\end{tabular}

This article is protected by copyright. All rights reserved. 


\section{Figure legends}

Fig. 1. Total biomass of (a) macroalgae and (b) gastropod grazers, and (c) total abundance of mesoinvertebrates for different levels of predator composition (no predators, whelk monocultures, crab monocultures and polyculture), nutrient enrichment (ambient and enriched) and warming (ambient and warmed). Inset in (a) shows algal biomass for different levels of warming pooled across predator composition and nutrient enrichment; inset in (b) shows grazer biomass for different levels of predator composition pooled across warming and nutrient enrichment and insets in (c) show abundance of meso-invertebrates for different levels of predator composition pooled across nutrient enrichment and warming and for different levels of nutrient enrichment pooled across predators. Lowercase letters indicate treatments that are statistically indistinguishable from each other based on SNK tests $(P>$ $0.05)$.

Fig. 2. (a) Gross assemblage productivity, (b) assemblage respiration and (c) net assemblage productivity for different levels of predator composition (no predators, whelk monocultures, crab monocultures and polyculture), nutrient enrichment (ambient and enriched) and warming (ambient and warmed). Insets show (a) gross assemblage productivity, (b) assemblage respiration and (c) net assemblage productivity for different levels of predator composition, pooled across nutrient enrichment and warming and for different levels of warming pooled across predator composition and nutrient enrichment. Lower case letters indicate treatments that are statistically indistinguishable from each other based on SNK tests $(P>0.05)$.

This article is protected by copyright. All rights reserved. 

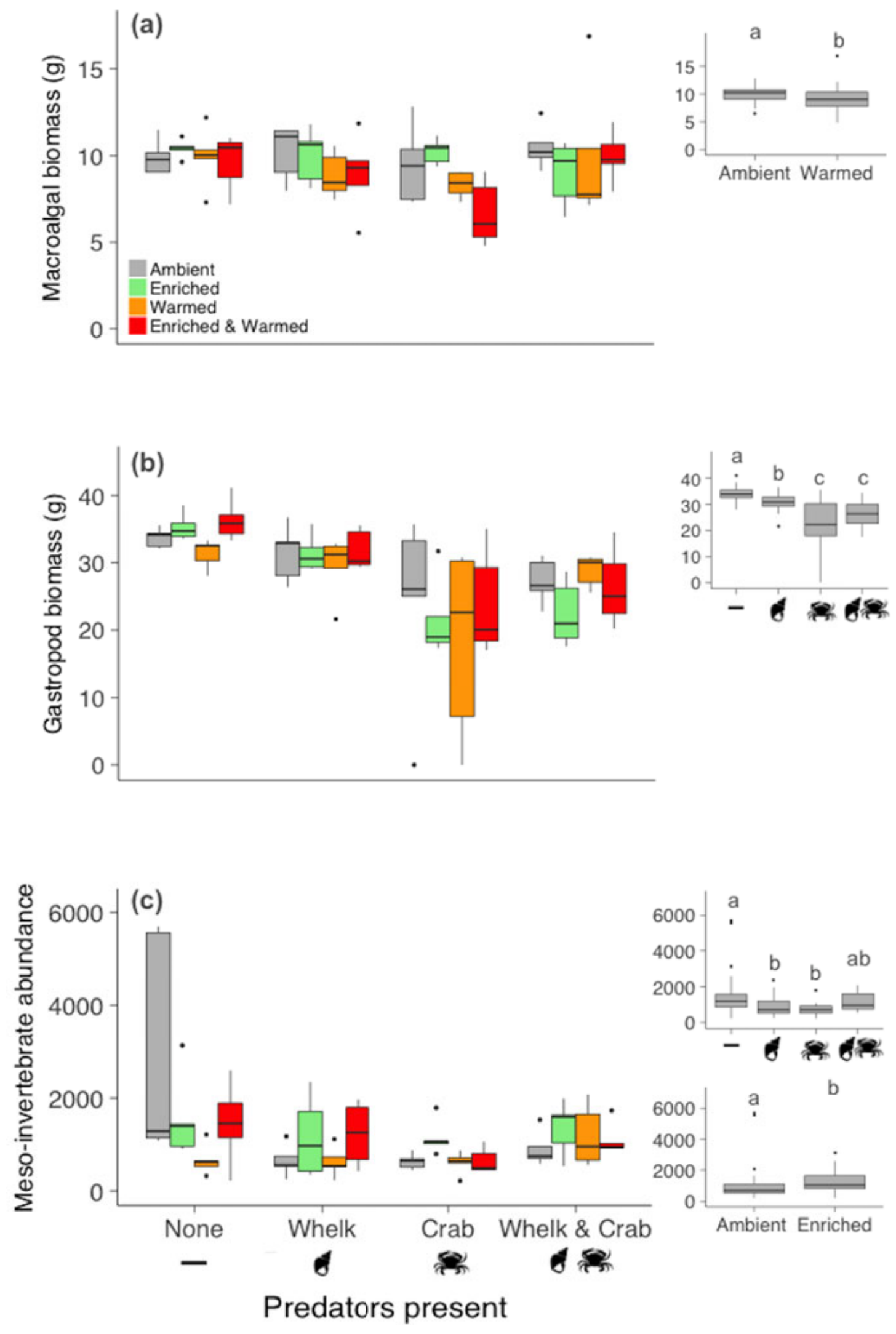

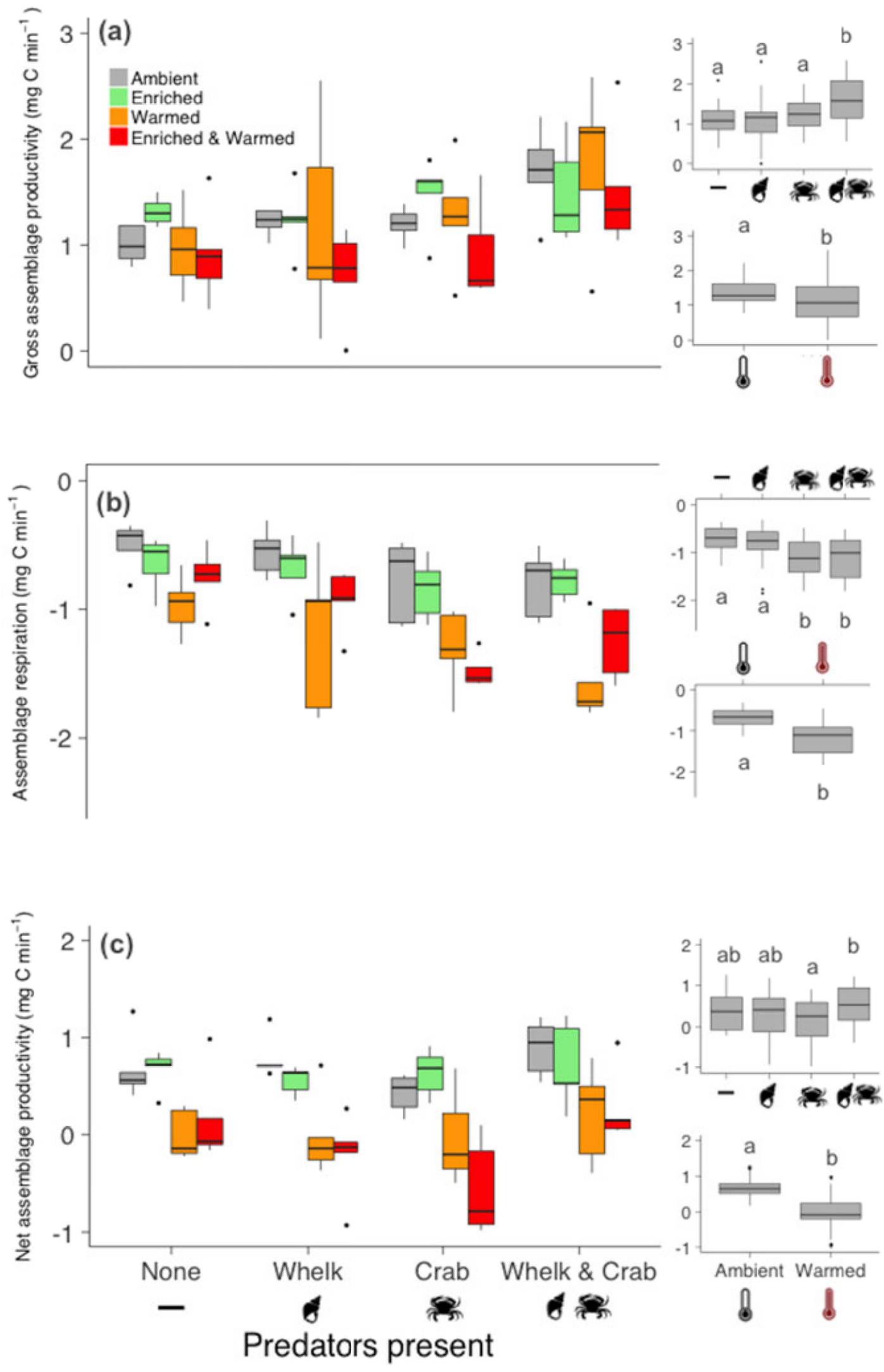

\& \& 